\title{
AdMinistrative SPECIALIST STAFF IN SAXONY - TOPICAL CHALlENGES AT THE EXAMPLE OF THE MEISSEN UNIVERSITY OF APPLIED ADMINISTRATIVE SCIENCES
}

\author{
FRANK NOLDEN*
}

\begin{abstract}
INTRODUCTION
This text is an elaborated transcript of a presentation given at the symposium "Current research problems in Administrative Studies in Germany and Poland", held at the University of Wrocław, October $21^{\text {st }}-22^{\text {nd }}$ 2016. It highlights the demographic challenges in the administrative sector for the Freestate of Saxony, measures taken at Meissen University of Applied Administrative Sciences, as well as possible strategies of the Freestate of Saxony regarding the public sector to meet the challenges of the coming decades ${ }^{1}$.
\end{abstract}

\section{OUtline OF The Challenge}

The Saxon universities play a prominent role in offering and realising solutions for the demographic challenges the Freestate of Saxony faces. Currently, there are 14 universities and universities of applied sciences with different specialisations (see fig. 1).

DOI: $10.1515 /$ wrlae-2015-0049

* Professor, PhD in Law, President of Meissen University of Applied Administrative Sciences, Centre for Continuing Education; frank.nolden@hsf.sachsen.de

${ }^{1}$ Final report of the personnel-commission ("Kommission zur umfassenden Evaluation der Aufgaben, Personal- und Sachausstattung"), imposed by the Saxonian Government, 2016. 
Fig. 1 Location of universities in the Freestate of Saxony

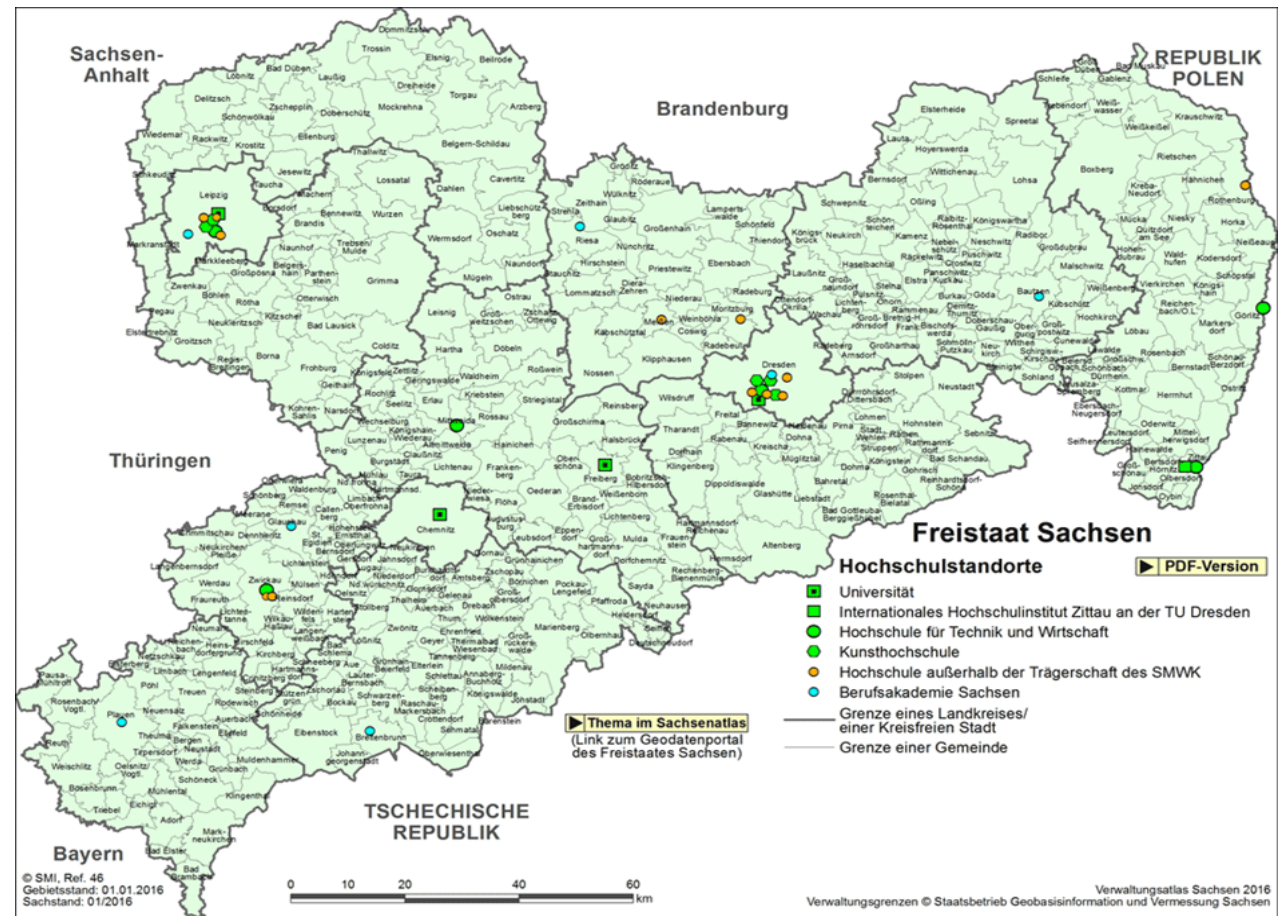

\section{Source:}

http://www.verwaltungsatlas.sachsen.de/img/img_verwaltungsatlas/Verwaltungsatl as/hochschule.gif

Two universities of applied sciences are responsible for the education for the public sector. One of them, situated close to Görlitz, exclusively trains students for the Saxon police force ${ }^{2}$; the other, situated close to the Saxon capital Dresden, in Meissen, qualifies students in the departments of financial and tax administration, social administration and social security, administration of justice, and general administration (state administration as well as communal administration, i.e. for municipalities, cities and districts) ${ }^{3}$.

The graduates then enter the public sector at the so-called 1. entry level for the public service category 2. The layering of the personnel in Saxony is smallest at the level of the higher civil service (mostly jurists), and highest at the level of the upper intermediate civil service (all graduates of Meissen University of Applied Sciences) as well as at the level of the intermediate civil service (mostly after vocational training). The demographic development in eastern Germany (the former territory of the GDR) is especially regressive, in particular in the rural areas. Currently, the bigger cities such as Dresden, as the state capital, as well as Leipzig and Chemnitz, see a considerable increase of their population. The development of the population and the age structure are illustrated in the fig. 2 .

\footnotetext{
${ }^{2}$ Hochschule der Polizei (FH) - Saxonian Police University.

${ }^{3}$ Hochschule Meissen (FH) und Fortbildungszentrum des Freistaates Sachsen - University of Applied Administrative Sciences Meissen.
} 
Fig. 2 Population prognosis (Population in the Free State of Saxony 1990 to 2030)

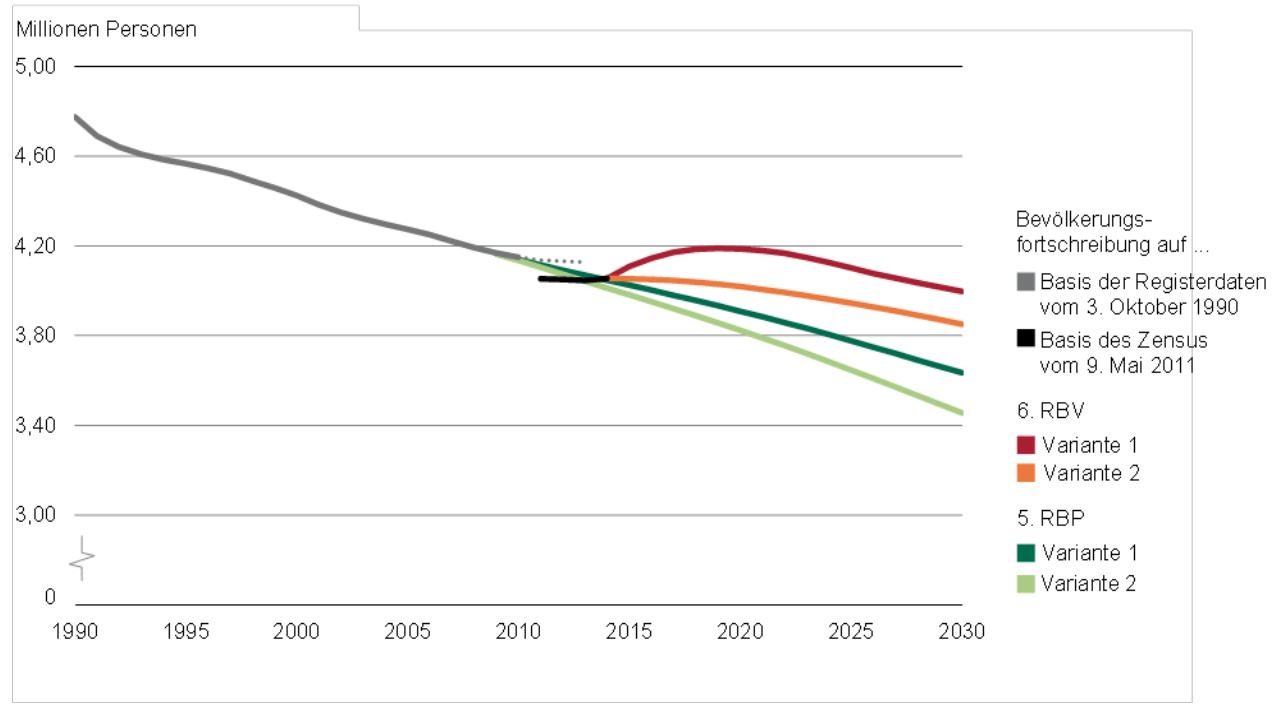

Source: Saxonian Statistical Office und Head Office of the personnelcommission (Personalkommission) 2016.

The statistical office of the Freestate of Saxony calculated a population forecast. For the years 1990 till 2030, there is a considerable, even dramatic, population decrease from 4.7 million inhabitants in 1990 to 3.5-3.9 million inhabitants in 2030. In addition, the share of the population aged 60 or over increases from 100.000 in 1990 to ca. 270.000 persons in 2030 and stays at this high level (see fig. 3).

Fig. 3 Increase of the Saxonian population $60+$

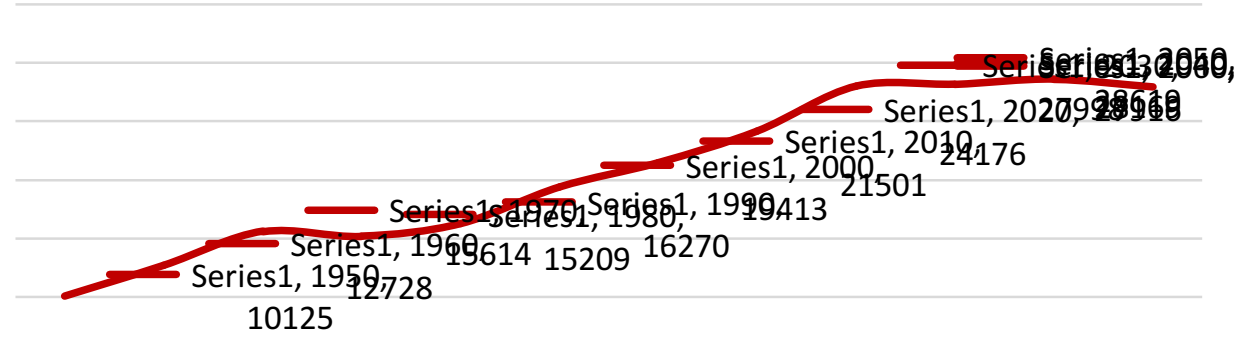

Source: Federal Statistical Office and ifo „Institut für Wirtschaftsforschung e.V." in Munich (branch Dresden).

The age structure of civil servants in Saxony shows a share of $28 \%$ of employees aged 60 or over; the share of employees aged 50 or over is $67 \%$ of all employees (with an absolute number of employees of 84.362 on 
January $1^{\text {st }}$ 2015). This data does not include the communal level, i.e. municipalities, cities and districts, and their large number of employees.

\section{CONSEQUENCES}

This initial situation will lead to a loss of personnel in the regional government and in the communities of about $50 \%$ in the years 2016 to 2030 as is illustrated in the fig. 4 .

Fig. 4 Age structure of civil servants in Saxony

\section{Altersstruktur Freistaat Sachsen}

Zahl der Bediensteten absolut: $84.362^{*}$

Stand 1. Januar 2015

(total: 84362, only Freestateb\% (19)

$0 \%(21)$
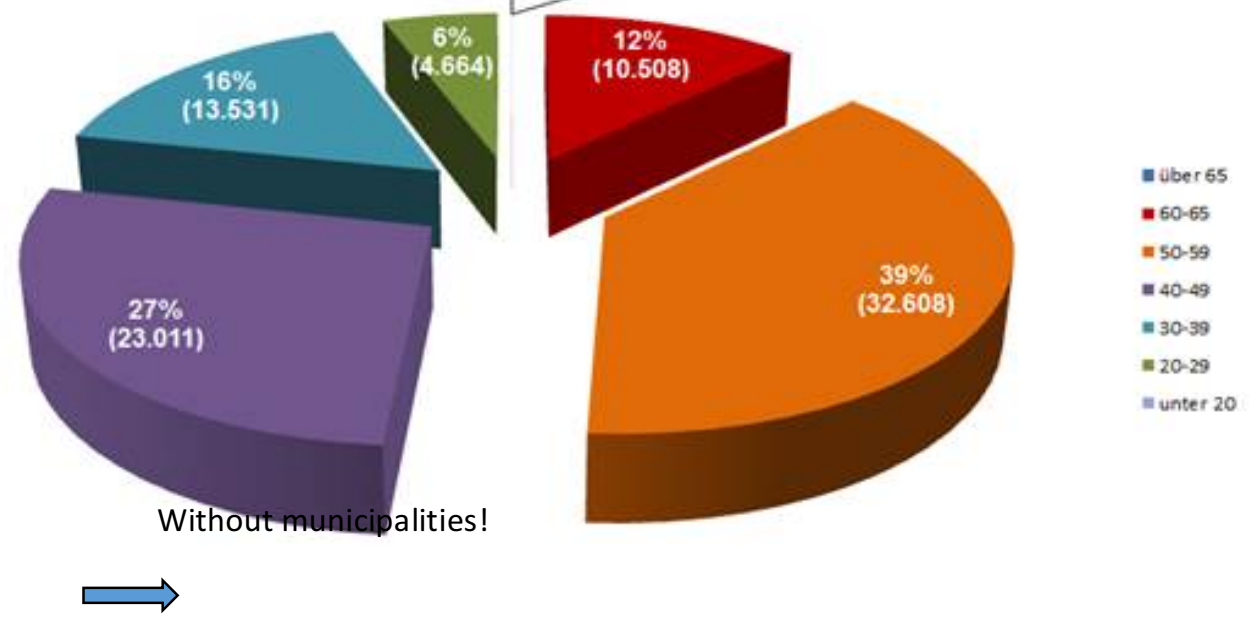

Source: Head Office of the personnel-commission (Personalkommission) 2016.

The loss of personnel will obviously lead to a considerable loss of knowledge and support for the (political) administrative sector in the Freestate of Saxony. This is highly correlated with a loss of praxis-oriented and experienced instructors - which are indispensable to representing a very significant distinctive feature of the dual education system in the higher education system. In addition, there is the imminent fast ageing of the public administration: there is a tendency to higher rates of sick leave among employees in conjunction with longer periods of sickness due to an increased average age of the employees ${ }^{4}$. There is also an increased utilisation of offers such as early partial retirement or part-time work among younger civil servants. The generation $55+$ that is leaving the labour market is often not prepared for the challenges of changing working environments and is not able to transmit knowledge in a digital form. In addition, there

\footnotetext{
${ }^{4}$ Epidemiologisches Gutachten im Auftrag des Bundesministeriums für Familie, Senioren, Frauen und Jugend (BMFSFJ) - Präsentation bei der Fachtagung zum Thema „Gesellschaftliche Teilhabe im Alter. Welche flexiblen Altersgrenzen brauchen wir in Zukunft?", am 10.12.2013 in Berlin [http://www.iges.com/e2856/e4186/e8617/e8618/e8648/e8649/attr objs8655/IGES Gesel 1schaftliche Teilhabe imAlter Dr.Schueler ger.pdf].
} 
may be so-called generation conflicts, especially in cases of process optimisation and in the IT-sector. Older employees are often less willing to accept innovations. In addition, missing personnel complicates the practical education in universities. All universities, the University of Applied Administrative Sciences in Meissen included, experience a tendency towards less adequate applicants in quality and quantity for the course of studies. There is also a noticeable competition with trade and industry which will lead to further decreasing numbers of applicants. A specific challenge for the rural administrations is the decreasing willingness of graduates from Meissen University of Applied Administrative Sciences to work in rural areas and to choose those areas as places of residence ${ }^{5}$. This intensifies the haemorrhaging of the rural areas, as the fig. 5 shows.

Fig. 5 Change to the population size 2011 to 2015 in Saxony

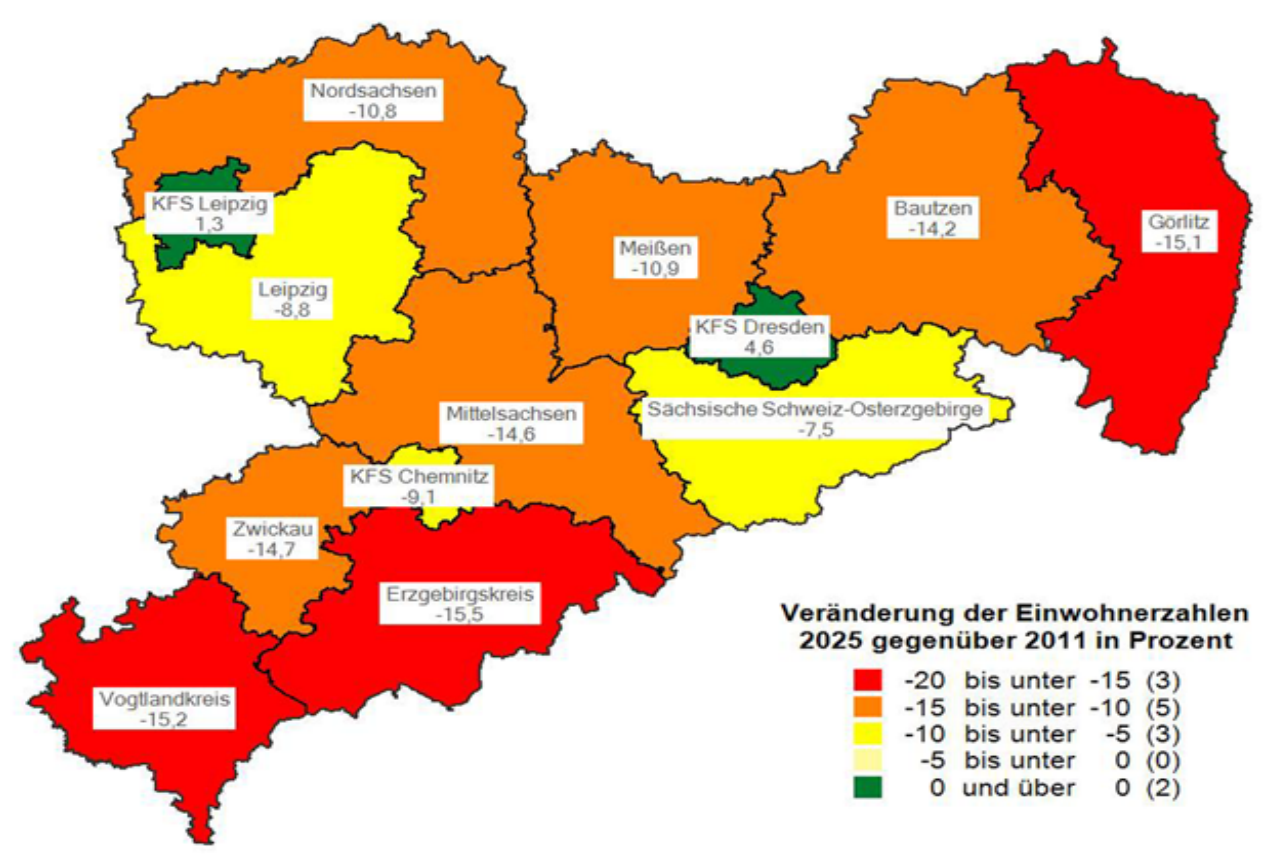

Source: $\underline{w w w . d e m o g r a p h i e-p o r t a l . d e}$

The education at the University of Applied Administrative Sciences in Meissen itself takes three years, therefore, a quick increase of the number of graduates for the Freestate and the communal level is impossible. In addition, the preparation time for choosing and winning students, i.e., for the application and selection procedures (which in Meissen are similar to the French Concours), is about one year. The long-term practice of understaffing led, among other consequences, to a skewed personnel structure; i.e., too many older, and too few younger, employees. There is

\footnotetext{
${ }^{5}$ Ländliche Lebensverhältnisse in Sachsen: Ergebnisse einer Repräsentativbefragung im Freistaat Sachsen - Zentrale Ergebnisse - done by forsa (Gesellschaft für Sozialforschung und statistische Analysen mbH Berlin), 2014

[https://publikationen.sachsen.de/bdb/artikel/21033/documents/28373].
} 
also a real risk of a repetition of the situation of the 1990s with a quick staff recruitment, which in time led to bottlenecks for promotions. Furthermore, quickly recruiting a large number of personnel at a late time may lead to a violation of the principle of selecting the best candidates, as had possibly happened in the 1990s. On the communal level, there are reports that expert staff from smaller communes are recruited by larger communes, because they can offer better options for development and promotion (see fig. 6).

Fig. 6 Rural regions in the eastern part of Germany suffer the scourge of emigration

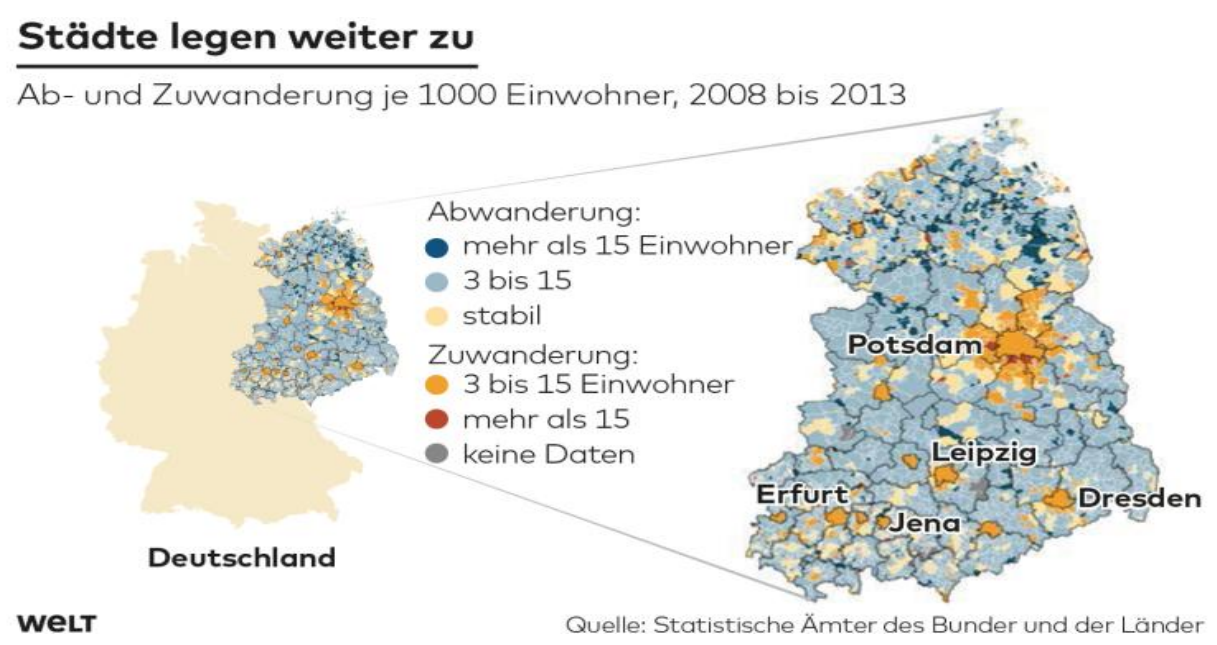

Source: Federal Statistical Office and Statistical Offices of the Bundesländer

The number of applicants is stagnating at a high level of about 1.700 applicants for about 200 places at the University of Applied Administrative Sciences in Meissen, i.e., about eight or nine applicants for every available place. The numbers of new matriculations, which at the same time mean an employment with an administrative unit in a dual system, are increasing only slightly

\section{DeMAND ON THE Federal State LeVEl UNTIL 2030}

The internal administration of the Freestate of Saxony alone will need to qualify and employ 1.200 persons between 2016 and 2030 (see fig. 7). 
Fig. 7 Need at State Level Saxonia (Only General Management)

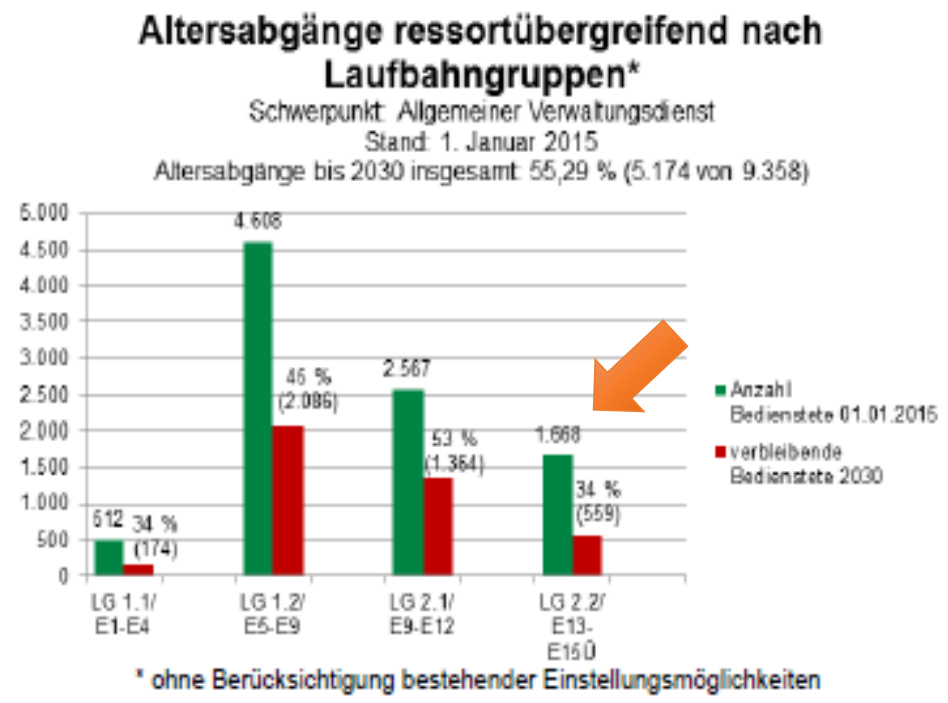

Source: Head Office of the personnel-commission (Personalkommission), 2016.

Statement of the personnel-commission (Personalkommission): Up to 2030 approx. 1.200 Civil servants are needed.

This is an immense challenge for the University in Meissen. A class in universities with a structure like the one in Meissen must not include more than 30 (ideally, not more than 25) students. An additional class necessitates an increase in teaching staff of 1.5 persons in Academia and a full-time equivalent of 0.5 persons in the administration. This implies for the Freestate that with an additional four groups, there is an increase of personnel of at least 8 persons, or more if the increase in the number of classes is even higher.

\section{Measures Taken by Meissen University of APPliEd AdMinistrative SCIENCES}

The university presented a first strategy document for the Ministry of the Interior in 2014 and suggested to expand the university analogous to the French École Nationale d'Administration (ENA). In the beginning of 2015, a task group was established at the ministry. It did not have any immediate results, but in 2016, the state government established a personnel commission at the state chancellery that was to analyse the personnel requirements under the given circumstances in preparation for the cabinet dealing with the topic in 2017. These preparations are ongoing and will presumably be completed as planned on 31.03.2017. The university implemented the so-called Academy for the Public Administration of the Freestate of Saxony (as a centre for continuing education for all ministries of state). This increases the chance to offer a customer-oriented and modern continuing education in addition to the regular modern and ambitious 
university education. The university, after a long-term reduction of personnel in academia and administration, currently faces a situation where teaching can only be ensured by employing personnel that is regularly employed elsewhere for specific teaching modules. In addition, there are more delegated teaching staff, and the professional instructors must accept higher teaching loads. It has to be stated that specialists and young instructors are scarce or cannot be found at all anymore.

In spite of these challenges, the university implemented a master programme for Public Governance ${ }^{6}$ that started on 12.09.2016 and is a further development of the existing successful part-time master programme Administrative Informatics. The development of a part-time curriculum for the master programme Public Governance includes four main fields:

- $\quad$ legal and administrative sciences,

- $\quad$ economics and management,

- $\quad$ information processing (in the broader sense)

- $\quad$ and process management.

The programme aims at providing interdisciplinary competences and specifications in the areas of management and process orientation as well as in the information technology, with an additional focus on teaching legal and economic aspects on a more global and complex level. The intention in conjunction with the demands of the customers, i.e., bigger communes as well as the Freestate - to educate future executives as generalists.

\section{Possible Strategies of the Freestate}

One strategic perspective for the Ministry of the Interior, in addition to the intended education offensive of the state chancellery, is to develop an education initiative with the help of Meissen University of Applied Administrative Sciences that needs the corresponding personnel endowment as well as improved financial and infrastructural equipment. The fact that there is an enormous increase in the demand for practical instructors that can only be supplied in cooperation with all levels of the administration supports the importance of a joint education initiative. This need for a practical education can only be met if significantly more persons are willing to support the students from Meissen during their practice periods and to prepare them for their challenging future jobs, in spite of the increased workload in the administration. The joint education initiative should be accompanied by an initiative for continuing education, which the centre for continuing education in Meissen ${ }^{7}$ is prepared to support: The aim is to prepare current executives that are responsible for the management of the demographic changes for their work in a changing, digitalised work environment, for example by preparing them for the transition of knowledge to the next generation of employees. Therefore, an increased discussion of knowledge management as well as a stronger concentration on processes and their optimisation is essential and should be discussed and taught

\footnotetext{
${ }^{6} \mathrm{https://www.fhsv.sachsen.de/studium/public-governance/.}$

7 http://www.avs.sachsen.de/.
} 
together with questions on project management within programmes of continuing education.

Due to requests from bigger communes, the introduction of a parttime bachelor for general administration is discussed. It would likely last for three years or more and would be suited for employees on the intermediate level of the civil service. An according request of the three large cities implies that the formation of a test-class may be expedient and may support the upper intermediate level of the civil service with its special knowledge and experiences. Whether this project is sustainable remains to be seen.

In addition the Freestate, in conjunction with the university in Meissen, considers whether students from neighbouring states such as Thuringia, Bavaria and especially Brandenburg should be included to also attract German-speaking students from the Czech Republic and Poland. This would support the European spirit as well, by bringing together the peoples from border regions such as the district of Görlitz or the regions on the borders to the Czech Republic in the Erzgebirge or the Vogtland.

\section{InCREASIng The AtTractivity OF The Civil Service}

The Freestate should strongly consider increasing the attractiveness of working in the civil service ${ }^{8}$, e.g., by employment guarantees and other monetary or non-monetary incentives, by development of career paths as already shown by some communes, but also by addressing of new target groups, e.g., by prioritising the education in the IT-sector and in process management. Last but not least, the development of Meissen University of Applied Administrative Sciences to a central venue for continuing education of civil servants across administration areas (also, and especially, executives) of the Freestate and the communes, by using its comprehensive competences in the legal, economic and IT education, has to be discussed. This would support the university which currently is already an important venue for undergraduate programs for all aspects of public activity.

\section{CONCLUSION}

The measures suggested offer the Freestate of Saxony a chance to successfully shape and organise the demographic change in spite of a decrease of personnel and a loss of knowledge, by using optimised digital techniques based on a solid professional training.

\footnotetext{
${ }^{8}$ Kristin Klunker: (Un-)Attraktivität des öffentlichen Dienstes in Deutschland? - Wege zur Deckung des Personalbedarfs unter Berücksichtigung der Konzepte in ausgewählten europäischen Staaten, Abschlussarbeit im Master-Fernstudiengang Europäisches Verwaltungsmanagement an der Hochschule für Wirtschaft und Recht Berlin und an der Technischen Fachhochschule Wildau am Studienzentrum Brühl (Fachhochschule des Bundes für öffentliche Verwaltung), 2009

[http://www.verwaltungsmanagement.info/docs/Klunker Attraktivitaet des oeffentl Dienstes 2009.pdf].
} 